\title{
Conditioned taste aversion: potential for reducing cattle loss to larkspur
}

MARK A. LANE, MICHAEL H. RALPHS, JOHN D. OLSEN, FREDERICK D. PROVENZA, AND JAMES A. PFISTER

\section{Abstract}

Barbey larkspur (Delphinium barbeyi L. Huth) is a palatable poisonous plant that causes a large number of cattle deaths on mountain rangelands. The objective of the study was to determine whether or not cattle could be conditioned to avoid eating larkspur. Five heifers were conditioned to avoid eating larkspur by intraruminal infusion of lithium chloride whenever they consumed larkspur in a pen feeding trial. Five control heifers were likewise infused with distilled water. Following the conditioning, the heifers were taken to mountain rangeland in central Utah and observed in 1986 and 1987. The non-averted heifers consumed larkspur throughout the 1986 field trial, while the averted heifers generally consumed little larkspur. The aversion from the previous summer persisted as the averted heifers refused to eat larkspur in the first grazing trial in 1987. During the second grazing trial in 1987, the averted heifers were placed in a pasture with non-averted heifers to determine if social influences would affect learned aversions. $A$ rapid breakdown of the aversions was observed and the averted heifers continued consuming larkspur after being separated from non-averted heifers.

Key Words: conditioned food aversion, social facilitation, poisonous plants, cattle diets, Delphinium barbeyi

Consumption of various species of larkspur (Delphinium spp.) causes more cattle deaths on mountain ranges than any other poisonous plant (Kingsbury 1964, Cronin and Nielsen 1981, James 1983). Of particular importance is Barbey larkspur (Delphinium barbeyi L. Huth), which is toxic to both cattle and sheep (Olsen 1978). The toxic components in Barbey larkspur are diterpenoid alkaloids of which peak concentrations occur during periods of rapid growth but decline thereafter (Williams and Cronin 1966). Cattle become intoxicated by eating large amounts of the plant over a short period of time, whereby rate of absorption and metabolism of alkaloids exceeds rate of excretion (Olsen 1983, Crawford 1907).

Methods of mechanical control of larkspur are generally impractical and chemical control is costly. Because larkspur patches are abundant, ir regularly shaped, and variable in size, conventional fencing and herding are also generally deemed impractical (Cronin and Nielsen 1981).

An alternative to larkspur control is to train cattle to avoid consuming the plant (Provenza and Balph 1987, 1988). Cattle, sheep, and goats have been found to avoid specific foods when ingestion of the food is followed by gastrointestinal distress (Zahorik and Houpt 1977, 1981; Olsen and Ralphs 1986; Thorhallsdottir et al. 1987). The objective of this study was to determine if cattle could be trained to avoid eating larkspur in pen and field-grazing conditions, and if so, to determine how long the aversion might persist.

\footnotetext{
Lane is district conservationist, SCS, Simla, Colo. 80835. During the research he was a graduate student, range science, Utah State University, Logan 84322 . Ralphs, Olsen, and Pfister are range scientist, veterinary medical officer, and range scientist, respectively, USDA, Agricultural Research Service, Poisonous Plant Research Laboratory, Logan, Utah 84321; Provenza is associate professor, range science, Utah State University, Logan 84322 .

Utah Agricultural Experiment Station, Journal Paper No. 3732.

Manuscript accepted 24 April 1989.
}

\author{
Methods
}

Aversion Conditioning

Aversions to larkspur were formed during the summer of 1986 at the USDA-ARS Poisonous Plant Research Laboratory in Logan, Utah. Ten yearling Hereford heifers, which spent the previous summer as calves on the Six-Mile Canyon Cattle Allotment (site of subsequent field studies), were purchased in the spring of 1986 . The heifers were gentled, blocked by weight and ownership, and randomly allocated to treatment groups ( $n=5$ per group). A blind rumen fistula was surgically installed in each heifer (Olson 1979). Catheters were inserted to infuse lithium chloride ( $\mathrm{LiCl})$, an emetic which causes gastrointestinal distress.

Fresh plants in the bloom stage were collected from the Six-Mile Allotment, transported to the Poisonous Plant Research Lab in Logan, and stored in a walk-in cooler at $2^{\circ} \mathrm{C}$ to keep them fresh and turgid throughout the conditioning experiment. Prior to conditioning, all heifers were offered a stalk of larkspur on each of 3 consecutive days to ensure that they would eat fresh larkspur when confined in stanchions.

Heifers were placed in locked stanchions and intraruminal tubes were attached for infusion of solutions. Conditioning protocol consisted of withholding normal evening feed, then offering each heifer 3 weighed stalks of larkspur (held upright in a container) during the normal morning feeding time $(0700$ to $0800 \mathrm{hr})$. Each heifer that consumed larkspur received an intraruminal infusion of $8 \% \mathrm{LiCl}$ ( $100 \mathrm{mg} \mathrm{LiCl} / \mathbf{k g}$ body weight). The control group was infused with the same volume of distilled water. Other feed was withheld for the rest of the day to ensure the heifers associated the digestive malaise with ingested larkspur. This procedure was repeated 6 times at 2- to 3-day intervals. The uneaten portions of larkspur and 10 reference stalks were dried at $60^{\circ} \mathrm{C}$ for $48 \mathrm{hr}$ and weighed. Percent dry weight was used to determine the percentage of larkspur eaten. Data were analyzed using repeated measures analysis of variance (ANOVA) comparing larkspur consumption between the 2 groups and among the days of the trial. Differences between groups were tested by the animal within group interaction, and differences among days and the day by group interaction were tested by the residual error.

\section{Field Trial, 1986}

Field studies were conducted in subalpine vegetation at $3,050 \mathrm{~m}$ on the Six-Mile Canyon Cattle Allotment on the Wasatch Plateau $\left(39^{\circ} 11^{\prime} \mathrm{N}^{\circ} 111^{\circ} 30^{\prime} \mathrm{W}\right.$ ) near Manti, Utah, during the summers of 1986 and 1987 . The tall forb community was dominated by Barbey larkspur. The remaining grass-forb mix was highly variable and dominated by mountain brome (Bromus ciliatus L.) and dandelion (Taraxacum officinale Wiggers). Patches of currant (Ribes montigenum McClatchie) and small groves of Englemann spruce (Picea engelmannii Parry ex Engelm.) also occurred in the area.

The 2 groups of heifers (averted and control) were placed in separate but adjacent pastures following conditioning. Diets were quantified by using a bite count technique (Bjugstad et al. 1970). Heifers were observed each day for several 5-min periods during 
Table 1. Larkspur consumption (\% of offered) during aversive conditioning in the pen trial and following the $\mathbf{1 9 8 6}$ field trial (data taken from Olsen et al. 1989).

\begin{tabular}{|c|c|c|c|c|c|c|c|c|}
\hline \multirow[b]{2}{*}{ Treatment } & \multicolumn{6}{|c|}{ Conditioning } & \multicolumn{2}{|c|}{ Persistence } \\
\hline & 1 & 3 & $\begin{array}{l}\mathrm{D} \\
5\end{array}$ & ys 8 & 10 & 12 & Mean & $\begin{array}{c}\text { Day } \\
44\end{array}$ \\
\hline $\begin{array}{l}\text { Averted } \\
\text { Control }\end{array}$ & $\begin{array}{l}100 \\
100\end{array}$ & $\begin{array}{r}72 \\
100\end{array}$ & $\begin{array}{r}2 \\
100\end{array}$ & $\begin{array}{l}<1 \\
100\end{array}$ & $\begin{array}{r}2 \\
100\end{array}$ & $\begin{array}{r}0 \\
100\end{array}$ & $\begin{array}{c}30^{* *} \\
100^{* *}\end{array}$ & $\begin{array}{r}0^{* * *} \\
67^{* *}\end{array}$ \\
\hline
\end{tabular}

$* \mathbf{P}<.01$

major grazing periods. Bites were classified as either grass, forb (other than larkspur), larkspur bloom, larkspur pod, or larkspur leaf. Percent composition of bites was calculated for each heifer on a daily basis. The study began on the morning of 12 August, 5 days after completion of aversion training, and continued for a total of 13 days. The percent of bites was analyzed by a repeated measure ANOVA, as described in the conditioning trial.

Herbage standing crop in each pasture was estimated at the beginning, middle, and end of the trial by the following procedure. Pastures were stratified by vegetation types: larkspur, grass-forb, and currant. In the larkspur vegetation type, ten $1 \times 1-\mathrm{m}$ quadrats were systematically located on a pace transect, clipped to ground level, and separated into grass, forb (other than larkspur), larkspur flower, larkspur leaf, and larkspur stem. Standing crop of the grass-forb type was estimated by systematically locating ten $0.25 \times$ $1-\mathrm{m}$ quadrats along a paced transect and clipping and separating vegetation into grass and forb. Standing crop of the currant vegetation occupied only a small area within pastures and was not measured. All herbage was dried in a forced-air oven at $60^{\circ} \mathrm{C}$ for $48 \mathrm{hr}$ prior to weighing. Larkspur phenology and utilization was determined at the middle and end of the trial by counting larkspur stems, blooms, stems and pods, and defoliated tops in ten $1 \times 1-\mathrm{m}$ quadrats systematically located on transects in the larkspur vegetation in each pasture.

Pasture size was determined by the initial standing crop, dry matter intake requirements of heifers, and length of the grazing period (NAS/NRC 1984). Desired densities were those necessary to obtain $50 \%$ utilization of grasses. However, the north pasture was subsequently found to be of inadequate size to attain desired levels of utilization. Thus, it was enlarged from 1.1 to 2.0 ha midway through the trial.

Following the field grazing trial, on day 44 , the heifers were returned to the pen and offered larkspur to evaluate persistence of the aversion in the context where it was created. The difference in larkspur consumption between the averted and control group was determined by one-way ANOVA.

\section{Trial 1, 1987-Persistence}

To determine if the aversion learned in 1986 would persist into 1987, the same averted heifers were returned to the field for a 16-day grazing trial beginning on $15 \mathrm{July}$. Bite counts were recorded as in the 1986 trial and analyzed by one-way ANOVA to determine differences among days.

The 6.2-ha pasture was stratified by vegetation type (larkspur, grass-forb, currant) and standing crops was estimated at the beginning of the trial, as described in the 1986 field trial, except that larkspur was not sampled. At the end of the trial, standing crop was estimated by using a herbage capacitance meter (Neal Model 18$3000)$ with readings taken on 30 quadrats $(30 \times 61 \mathrm{~cm})$ located in each vegetation type. Ten of the quadrats were clipped and vegetation was separated into grass, forb (other than larkspur), shrub, and larkspur leaf, stem, and flower. Total weights from clipped plots were used to develop a regression equation to estimate total standing crop. Percentage composition by plant class category was estimated by multiplying the total standing crop by average composition of clipped plants. Phenological growth stage of larkspur plants was estimated as in 1986.

\section{Trial 2, 1987-Social Facilitation}

The second field trial in 1987 was designed to determine if social interactions influenced the aversion to larkspur. Five yearling heifers from a grazing behavior study in an adjacent pasture (Pfister et al. 1988a) were used as controls. Averted and control heifers were placed in the same 3.8-ha pasture. Bite counts were recorded beginning 5 August for 10 consecutive days for both averted and non-averted heifers. Bite count data were analyzed by repeated measures ANOVA as described in the conditioning trial. Standing crop was estimated at the beginning and end of the trial using the herbage meter on 30 plots as described previously. Larkspur phenological growth stage and utilization were estimated as in previous trials.

\section{Trial 3, 1987-Persistence Following Social Facilitation}

This trial was conducted to measure persistence of aversion following the social facilitation trial without the influence of nonaverted heifers. Averted heifers were placed in a 1.8-ha pasture. Bite counts were recorded for 10 consecutive days beginning on 19 August. Data were analyzed by one-way ANOVA comparing days. Standing crop was estimated at the beginning and end of the trial and larkspur phenological growth stages were determined as above.

\section{Results}

\section{Aversion Conditioning}

Heifers infused with $\mathrm{LiCl}$ in the pen trial were successfully conditioned to avoid eating larkspur (Table 1). On the first day of conditioning, all heifers consumed larkspur. By day 3 , the treated group consumed only $72 \%$ of larkspur offered; 1 heifer ate no larkspur. Only 1 heifer ate a small amount of larkspur on days 5 and 8 , and 2 heifers ate small amounts of larkspur on day 10. By day 12 the entire averted group abstained from eating larkspur. In contrast, control heifers consumed $100 \%$ of larkspur within 0.5 to 3 min throughout the trial. The group-by-day interaction $(P<0.01)$

Table 2. Percentage of recorded bites of larkspur plant parts and other forage by averted and control heifers during fleld trials.

\begin{tabular}{|c|c|c|c|c|c|c|c|c|c|}
\hline \multirow[b]{2}{*}{ Year } & \multirow[b]{2}{*}{ Trial } & \multirow[b]{2}{*}{ Group } & \multicolumn{4}{|c|}{ Larkspur } & \multirow[b]{2}{*}{ Grass } & \multirow[b]{2}{*}{ Forb } & \multirow[b]{2}{*}{ Shrub } \\
\hline & & & Flower & Pod & Leaf & Total & & & \\
\hline 1986 & & $\begin{array}{l}\text { Averted } \\
\text { Control }\end{array}$ & $\begin{array}{l}0 \\
0.8\end{array}$ & $\begin{array}{l}0 \\
2.6\end{array}$ & $\begin{array}{l}0.1 \\
5.9\end{array}$ & $\begin{array}{l}0.1^{*} \\
9.3^{* *}\end{array}$ & $\begin{array}{l}26 \\
27\end{array}$ & $\begin{array}{l}74^{* *} \\
63^{* *}\end{array}$ & $\overline{-}$ \\
\hline 1987 & $\begin{array}{l}1 \\
2 \\
3\end{array}$ & $\begin{array}{l}\text { Averted } \\
\text { Averted } \\
\text { Control } \\
\text { Averted }\end{array}$ & $\begin{array}{l}0 \\
0.3 \\
2.8 \\
0\end{array}$ & $\begin{array}{l}0 \\
4.5 \\
1.9 \\
2.3\end{array}$ & $\begin{array}{l}0 \\
0.5 \\
1.1 \\
4.2\end{array}$ & $\begin{array}{l}0 \\
5.3 \\
5.8 \\
6.5\end{array}$ & $\begin{array}{l}29 \\
21 \\
20 \\
64\end{array}$ & $\begin{array}{l}69 \\
71 \\
74 \\
24\end{array}$ & $\begin{array}{l}2 \\
3^{*} \\
1^{*} \\
5\end{array}$ \\
\hline
\end{tabular}

$* P<.05, * * P<.01$ 
Table 3. Density ( \pm standard error), phenological development, and utilization of larkspur during field trials.

\begin{tabular}{|c|c|c|c|c|c|c|c|c|}
\hline \multirow[b]{2}{*}{ Trial } & \multirow[b]{2}{*}{ Pasture } & \multirow[b]{2}{*}{ Time } & & & \multicolumn{3}{|c|}{$\begin{array}{l}\text { Pehnological growth stage } \% \text { of } \\
\text { reproductive stems }\end{array}$} & \multirow[b]{2}{*}{ Defoliated stalks } \\
\hline & & & \multicolumn{2}{|c|}{ Density } & Bud & Flower & Pod & \\
\hline 1986 & $\begin{array}{l}\text { Averted } \\
\text { Control }\end{array}$ & $\begin{array}{l}\text { Middle } \\
\text { End } \\
\text { Middle } \\
\text { End }\end{array}$ & $\begin{array}{c}\text { Stems/n } \mathbf{n} \\
28 \\
34 \\
40 \\
26\end{array}$ & $\begin{array}{r}\text { SE } \\
8 \\
4 \\
11 \\
3\end{array}$ & $\begin{array}{l}0 \\
0 \\
0 \\
0\end{array}$ & $\begin{array}{r}100 \\
52 \\
78 \\
36\end{array}$ & $\begin{array}{r}0 \\
48 \\
22 \\
64\end{array}$ & $\begin{array}{c}0 \\
1 \\
1 \\
23\end{array}$ \\
\hline $\begin{array}{l}1987 \\
\text { Trial } 1\end{array}$ & & $\begin{array}{l}\text { Begin } \\
\text { End }\end{array}$ & & & $\begin{array}{r}93 \\
4\end{array}$ & $\begin{array}{r}7 \\
82\end{array}$ & $\begin{array}{r}0 \\
14\end{array}$ & $\begin{array}{l}0 \\
0\end{array}$ \\
\hline Trial 2 & & $\begin{array}{l}\text { Begin } \\
\text { End }\end{array}$ & 13 & 2 & $\begin{array}{r}23 \\
0\end{array}$ & $\begin{array}{l}64 \\
13\end{array}$ & $\begin{array}{l}13 \\
87\end{array}$ & $\begin{array}{r}0 \\
68\end{array}$ \\
\hline Trial 3 & & $\begin{array}{l}\text { Begin } \\
\text { End }\end{array}$ & 20 & 5 & $\begin{array}{r}0 \\
\text { NA }\end{array}$ & $\begin{array}{r}7 \\
\text { NA }\end{array}$ & $\begin{array}{r}93 \\
\text { NA }\end{array}$ & $\begin{array}{r}0 \\
100\end{array}$ \\
\hline
\end{tabular}

reflects decreased consumption by the averted group.

\section{Field Trial-1986}

Control heifers ate varying amounts of larkspur throughout the field trial (Fig. 1). They preferred larkspur pods for the first 9 days of the trial and the proportion of larkspur flowers declined. Following an intense storm on 21-22 August, heifers abruptly selected more larkspur leaves. On 22 August, larkspur accounted for $26 \%$ of all bites (larkspur leaves accounted for $25 \%$ of all bites) taken by control heifers.

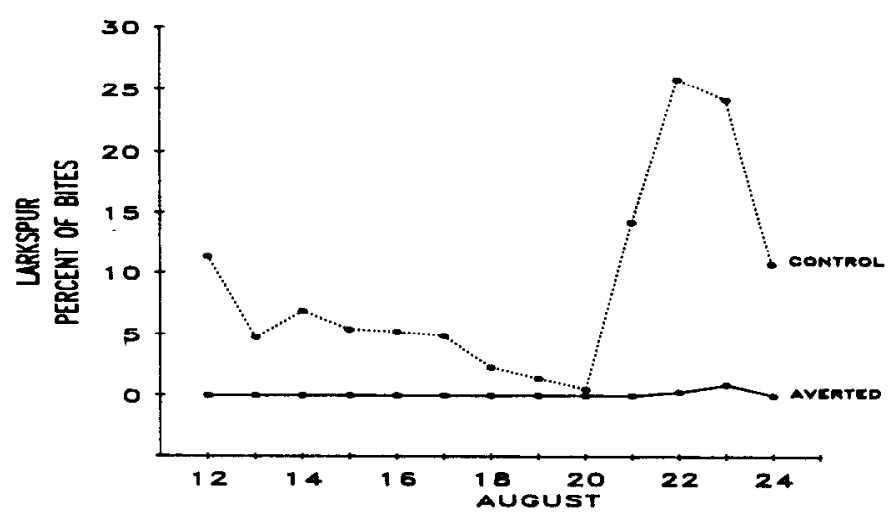

Fig. 1. Percentage of bites of larkspur by averted and control heifers during the 1986 field trial.

Table 4. Forage availability (kg/pasture) in the 1986 and 1987 field trials.
Consumption of larkspur by averted heifers was minimal compared to that by control heifers (Table 2). Averted heifers did not eat larkspur until 22 August (Fig. 1). After the intense rainstorm, 1 averted heifer ate 10 bites of larkspur leaves. On the following day, this heifer and 1 other heifer ate 24 bites of larkspur leaves. On the last day of the trial, the averted heifers ate no larkspur.

Both groups of heifers had access to larkspur in various phenological growth stages during the trial (Table 3). At the end of the trial, $23 \%$ of the larkspur stalks in the control group pasture and only $1 \%$ of the stalks in the averted group pasture had been defoliated. Averted heifers' bites of forbs $(74 \%)$ were greater $(P=.008)$ than the control group (63\%) (Table 2). There was no difference $(P=.677)$ in the number of bites of grass between the 2 groups. The proportion of forage classes in heifer diets was about the same proportion of the forage classes in the standing crop (Table 4).

Following the trial, averted and control heifers were returned to the pens at Logan and offered larkspur. Averted heifers did not consume larkspur while control heifers consumed $67 \%$ of the larkspur offered (Table 1).

\section{Trial 1, 1987-Persistence}

Prior to the 1987 field studies, heifers averted in 1986 were offered larkspur stalks in the bloom stage in the pens. The averted heifers consumed no larkspur.

The averted heifers did not eat larkspur throughout the persistence trial (Table 2). Most of the larkspur was in a bud stage at the beginning of the trial and matured to bloom stage; some formed pods by the end of the trial (Table 3). Thus, larkspur was available

\begin{tabular}{|c|c|c|c|c|c|c|c|c|c|c|c|}
\hline Trial & Pasture & $\begin{array}{l}\text { Pasture } \\
\text { Size (ha) }\end{array}$ & Time & Head & Leaf & Stem & Total & Forb & Grass & Shrub & Total \\
\hline \multirow[t]{2}{*}{1986} & Averted & $\begin{array}{l}1.1 \\
2.0^{1}\end{array}$ & $\begin{array}{l}\text { Begin } \\
\text { Middle } \\
\text { End }\end{array}$ & $\frac{20}{26}$ & $\frac{125}{94}$ & $\frac{157}{91}$ & $\frac{302}{211}$ & $\begin{array}{c}584 \\
1707^{1} \\
789\end{array}$ & $\begin{array}{l}378 \\
952^{1} \\
364\end{array}$ & $\begin{array}{l}- \\
-\end{array}$ & $\begin{array}{c}1264 \\
\frac{1}{1364}\end{array}$ \\
\hline & Control & 1.3 & $\begin{array}{l}\text { Begin } \\
\text { Middle } \\
\text { End }\end{array}$ & $\frac{60}{66}$ & $\frac{306}{241}$ & $\frac{321}{210}$ & $\frac{687}{659}$ & $\begin{array}{r}1113 \\
1081 \\
192\end{array}$ & $\begin{array}{c}470 \\
625 \\
-\end{array}$ & $\overline{-}$ & $\begin{array}{c}2270 \\
-\end{array}$ \\
\hline 1987 & $\begin{array}{l}1 \\
2 \\
3\end{array}$ & $\begin{array}{l}6.2 \\
3.8 \\
1.8\end{array}$ & $\begin{array}{l}\text { Begin } \\
\text { End } \\
\text { Begin } \\
\text { End } \\
\text { Begin } \\
\text { End }\end{array}$ & $\begin{array}{l}-79 \\
34 \\
24 \\
71 \\
11\end{array}$ & $\begin{array}{r}- \\
362 \\
215 \\
222 \\
286 \\
64\end{array}$ & $\begin{array}{l}- \\
505 \\
243 \\
295 \\
388 \\
237\end{array}$ & $\begin{array}{l}- \\
946 \\
492 \\
541 \\
745 \\
312\end{array}$ & $\begin{array}{r}5319 \\
4849 \\
3239 \\
2115 \\
896 \\
504\end{array}$ & $\begin{array}{r}831 \\
1423 \\
653 \\
579 \\
510 \\
169\end{array}$ & $\begin{array}{r}- \\
342 \\
279 \\
289 \\
47 \\
6\end{array}$ & $\begin{array}{r}- \\
7560 \\
4681 \\
3524 \\
2198 \\
991\end{array}$ \\
\hline
\end{tabular}

IPasture size was increased at mid-trial to avoid running out of feed. 
at all stages of growth during the trial. In a concurrent study of grazing behavior, non-averted heifers selected larkspur for $8 \%$ of their bites (Pfister et al. 1988a). The averted heifers chose forbs as $69 \%$ of their bites, grasses $29 \%$, and elderberry (Sambucus racemosa L.) $2 \%$.

A storm during the trial did not result in the heifers consuming larkspur. However, 3 cows in the allotment outside the trial pasture died from larkspur poisoning following the storm.

\section{Trial 2, 1987-Social Facilitation}

The averted heifers ate no larkspur for the first 2 days of the trial (Fig. 2). However, following a storm on 7 August, averted and

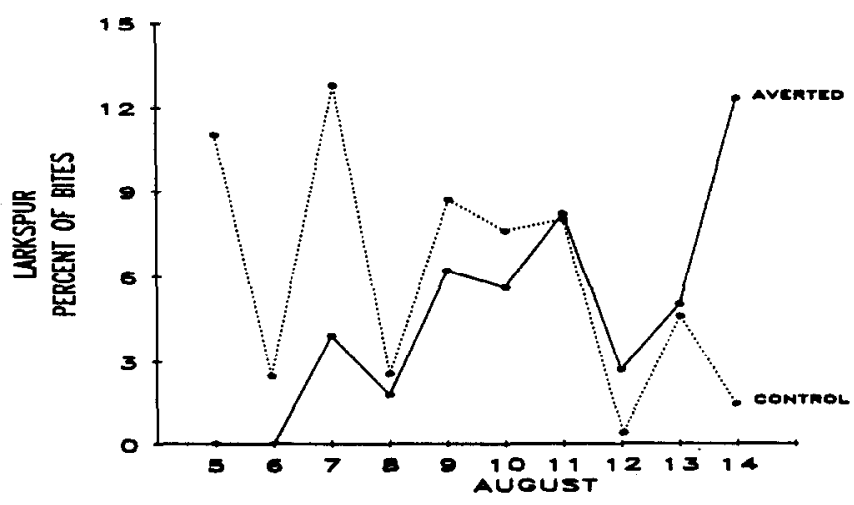

Fig. 2. Percentage of bites of larkspur by averted and control heifers during the 1987 social facilitation trial (2).

control heifers moved as a single group from one larkspur plant to another with heifers from both groups sniffing and eating pods. By the end of the trial, all averted heifers had consumed larkspur. Averted heifers averaged $5.3 \%$ of bites of larkspur during the trial while control heifers averaged $5.8 \%$. There were no differences $(P>0.05)$ in larkspur plant parts selected or in the amount of grass and forbs selected by averted and control heifers.

\section{Trial 3, 1987-Pensistence Following Social Facilitation}

Averted heifers, grazing alone, selected larkspur for $6.5 \%$ of all bites following exposure with non-averted heifers (Table 2). Leaves accounted for $4.2 \%$ of bites, while pods accounted for $2.3 \%$ (Table 2). A snowstorm on the evening of 25 August covered grasses and forbs in the pasture with snow and ice. Larkspur protruding above the the snow was one of few plants accessible to heifers. Heifers selected $12 \%$ of their bites as larkspur on 26 August. Larkspur leaves were selected for $8 \%$ of bites, stems for $3 \%$, and pods for $1 \%$ (Fig. 3). By the end of the trial, most of the reproductive tops were defoliated, leaves were stripped, and many were trampled.

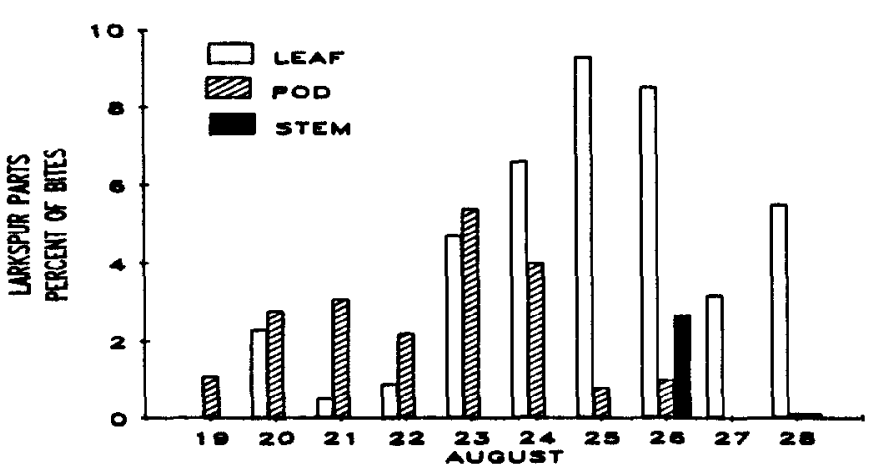

Fig. 3. Percentage of bites of larkspur plant part for averted heifers during the 1987 persistence following social interaction trial (3).
In this trial, heifers selected grass more than forbs, probably because grass was more available than forbs (Table 4). Grass accounted for $64 \%$ of bites, forbs $24 \%$, and browse $5 \%$. During the same period, non-averted yearling heifers in the study by Pfister et al. (1988a) selected larkspur as $10 \%$ of bites, grass $22 \%$, forbs $66 \%$, and browse $1 \%$.

\section{Discussion and Conclusion}

Heifers averted to fresh larkspur in pens subsequently avoided larkspur under free-ranging conditions. The data from 1987 indicate that the aversion persisted from 1986 into 1987. However, when averted heifers grazed with non-averted heifers in a 1:1 ratio, the averted heifers began to eat larkspur, which suggests that social interactions with non-averted heifers played a major role in extinguishing the aversion. Support for this hypothesis was garnered prior to this study when we found (unpublished) only 2 of 5 heifers would eat larkspur when the plant was presented to each individually, but all heifers ate larkspur when it was offered in a group situation. Olsen and Ralphs (1990) found that an aversion to alfalfa pellets persisted for 9 mo. when heifers were tested separately, but the aversion extinguished when alfalfa pellets were fed in a group situation with non-averted cohorts.

Results of the 1987 social facilitation trial were confounded by changes in plant phenology. As larkspur matures, a greater proportion of larkspur plants were in the pod stage, which appears to be the most palatable stage of growth (Pfister et al. 1988a, 1988b). Moreover, plant chemistry and resulting palatability may have been influenced by a rainstorm which increased larkspur consumption. Observations during this study and by ranchers and researchers (Pfister et al. 1988a, 1988b), indicate that cattle increase consumption of larkspur during and after rainstorms. Environmental factors can affect plant chemistry, which in turn affects use of plants by herbivores (Bryant et al. 1983, Gershenzon 1984).

Several factors associated with the pre-conditioning procedure may also have reduced the strength of the aversion. Studies with rats indicate that conditioned taste aversions are most effective when the food is novel (Rozin and Kalat 1971). Larkspur was probably not a novel food. Heifers may have eaten larkspur while grazing with their mothers on the allotment as calves. They also ate larkspur during preconditioning tests for acceptance.

The age at which conditioning occurs may also affect persistence. Young animals may be less likely to avoid foods that make them ill than mature animals. For example, lambs poisoned by LiCl-laced foods continually sampled these foods, but their mothers did not (Thorhallsdottir et al. 1987, Burritt and Provenza 1989). Likewise, mature animals do not accept new foods as readily as younger animals (Provenza and Balph 1988). For example, an experiment on learning ability and retention of learning showed that although heifers learn faster than cows, a cow's ability to recall past experiences is more stable (Kovalcik and Kovalcik 1986).

While our preliminary results are encouraging, more information is needed on the strength of social interactions, the importance of a novel food, the optimum age for conditioning, and refinement of the conditioning procedures. If social interactions can override conditioned taste aversions, conditioned animals could not be mixed with a group of non-averted animals, which would make management more complicated. However, if aversions could be conditioned in a manner that would enable animals to withstand social influences, it may be possible to condition replacement animals that could then be placed in a non-averted herd. If conditioned aversions are more persistent in older animals, perhaps 2year-old replacement heifers that have not been exposed to larkspur should be conditioned to avoid larkspur as a totally novel food. Practical methods of offering larkspur as a taste cue and administering the gastrointestinal poison must also be developed. 


\section{Literature Cited}

Bjugstad, A.J., H.S. Crawford, and D.L. Neal. 1970. Determining forage consumption by direct observation of domestic grazing animals. In: Range and wildlife habitat evaluation-a research symposium. USDA Forest Service, Misc. Pub. 1147.

Bryant, J.P., F.S. Chapin, III, and D.R. Klein. 1983. Carbon/nutrient balance of boreal plants in relation to vertebrate herbivory. Oikos 40:357-368.

Burritt, E.A., and F.D. Provenza. 1989. Food aversion learning: ability of lambs to distinguish safe from harmful foods. J. Anim. Sci. 67:1732-1739.

Crawford, A.C. 1907. The larkspur as poisonous plants. USDA. Bur. Plant Ind. Bull. 111.

Cronin, E.H., and D.B. Nielsen. 1981. Larkspurs and livestock on rangelands of western North America. Down to Earth 37:11-16.

Gershenzon, J. 1984. Changes in the levels of plant secondary metabolites under water and nutrient stress, p. 273-320. In: B.N. Timmerman, C. Steelink, and F.A. Loewus (eds.). Phytochemical adaptations to stress. Plenum Press, New York.

James, L.F. 1983. Poisonous plants: larkspur. Rangelands 5:169-170.

Kingsbury, J.M. 1964. Poisonous plants of the United States and Canada. Prentice-Hall, Inc., Englewood Cliffs, New Jersey.

Kovalcik, K., and M. Kovalcik. 1986. Learning ability and memory testing in cattle of different ages. Appl. Anim. Behav. Sci. 15:27-29.

NAS/NRC. 1984. Nutrient requirements of domestic animals. Nutrient requirements for beef cattle. 6 th revised ed. Nat. Acad. Sci., Washington, D.C.

Olsen, J.D. 1978. Tall larkspur poisoning in cattle and sheep. J. Amer. Vet. Assoc. 173:762.

Olsen, J.D. 1979. Method for repeated or prolonged rumen infusion without establishing an open fistula. Amer. J. Vet. Res. 40:730-732.

Olsen, J.D. 1983. Relationship of relative total duncecap alkaloid concentration and toxicity of duncecap larkspur during growth. J. Range Manage. 36:550-552.
Olsen, J.D., and M.H. Ralphs. 1986. Feed aversion induced by intraruminal infusion with larkspur extract in cattle. Amer. J. Res. Vet. Res. 47:1829-1833.

Olsen, J.D., and M.H. Ralphs. 1990. Persistence of feed aversion by intraruminal infusion of larkspur extract or lithium chloride in cattle. Appl. Anim. Behav. Sci. (in press)

Olsen, J.D., M.H. Ralphs, and M.A. Lane. 1989. Aversion to eating poisonous larkspur plants induced in cattle by intraruminal infusion with lithium chloride. J. Anim. Sci. 67:1980-1985.

Prister, J.A., G.D. Manners, M.H. Ralphs, Zhao Ziao Hong, and M.A. Lane. 1988a. Effects of phenology, site, and rumen fill on tall larkspur consumption by cattle. J. Range Manage. 41:509-514.

Pfister, J.A., M.H. Ralphs, and G.D. Manners. 1988b. Cattle grazing tall larkspur on Utah mountain rangeland. J. Range Manage. 41:118-122.

Provenza, F.D., and D.F. Balph. 1987. Diet learning by domestic ruminants: theory, evidence, and practical implications. Appl. Anim. Behav. Sci. 18:211-232.

Provenza, F.D., and D.F. Balph. 1988. The development of dietary choice in livestock on rangelands and its implications for management. J. Anim. Sci. 66:2356-2368.

Rozin, Paul, and J.W. Kalat. 1971. Specific hungers and poison avoidance as adaptive specializations of learning. Psych. Rev. 78:459-486.

Thorhalledottir, A.G., F.D. Provenza, and D.F. Balph. 1987. Food aversion learning in lambs with or without a mother: discrimination, novelty and persistence. Appl. Anim. Behav. Sci. 18:324-340.

Williams, M.C., and E.H. Cronin. 1966. Five poisonous weeds-when and why they are dangerous. J. Range Manage. 19:274-279.

Zahorik, D.M., and K.A. Houpt. 1977. The concept of nutritional wisdom: applicability of laboratory learning models to large harbivores, p. 45-67. In. L.M. Barker, M.R. Best, and M. Domjan (eds.). Learning mechanisms in food selection. Baylor Univ. Press.

Zahorik, D.M., and K.A. Houpt. 1981. Species differences in feeding strategies, food hazards, and the ability to learn food aversions, $p$. 289-310. In: A.C. Kamil and T.D. Sargent (eds.). Foraging Behavior. Garland, New York. 